\title{
Salmonella in Captive Reptiles and Their Environment-Can We Tame the Dragon?
}

\author{
Magdalena Zając ${ }^{1, *}$ D, Magdalena Skarżyńska ${ }^{1} \mathbb{D}$, Anna Lalak ${ }^{1}$, Renata Kwit ${ }^{1}$, Aleksandra Śmiałowska-Wegglińska ${ }^{1}$, \\ Paulina Pasim ${ }^{1}$, Krzysztof Szulowski ${ }^{1}$ iD and Dariusz Wasyl ${ }^{1,2}$ (D) \\ 1 Department of Microbiology, National Veterinary Research Institute, Al. Partyzantów 57, \\ 24-100 Puławy, Poland; magdalena.skarzynska@piwet.pulawy.pl (M.S.); anna.lalak@piwet.pulawy.pl (A.L.); \\ renata.kwit@piwet.pulawy.pl (R.K.); Aleksandra.Smialowska@piwet.pulawy.pl (A.Ś.-W.); \\ paulina.greszata@piwet.pulawy.pl (P.P.); kszjanow@piwet.pulawy.pl (K.S.); wasyl@piwet.pulawy.pl (D.W.) \\ 2 Department of Omics Analyses, National Veterinary Research Institute, Al. Partyzantów 57, \\ 24-100 Puławy, Poland \\ * Correspondence: magdalena.zajac@piwet.pulawy.pl; Tel.: +48-81-889-3419
}

Citation: Zając, M.; Skarżyńska, M.; Lalak, A.; Kwit, R.; ŚmiałowskaWẹglińska, A.; Pasim, P.; Szulowski, K.; Wasyl, D. Salmonella in Captive Reptiles and Their Environment-Can We Tame the Dragon? Microorganisms 2021, 9, 1012. https://doi.org/ 10.3390/microorganisms 9051012

Academic Editor: Jorge Blanco

Received: 30 March 2021

Accepted: 4 May 2021

Published: 8 May 2021

Publisher's Note: MDPI stays neutral with regard to jurisdictional claims in published maps and institutional affiliations.

Copyright: (c) 2021 by the authors. Licensee MDPI, Basel, Switzerland. This article is an open access article distributed under the terms and conditions of the Creative Commons Attribution (CC BY) license (https:/ / creativecommons.org/licenses/by/ $4.0 /)$.

\begin{abstract}
Reptiles are considered a reservoir of a variety of Salmonella (S.) serovars. Nevertheless, due to a lack of large-scale research, the importance of Reptilia as a Salmonella vector still remains not completely recognized. A total of 731 samples collected from reptiles and their environment were tested. The aim of the study was to assess the prevalence of Salmonella in exotic reptiles kept in Poland and to confirm Salmonella contamination of the environment after reptile exhibitions. The study included Salmonella isolation and identification, followed by epidemiological analysis of the antimicrobial resistance of the isolates. Implementation of a pathway additional to the standard Salmonella isolation protocol led to a $21 \%$ increase in the Salmonella serovars detection rate. The study showed a high occurrence of Salmonella, being the highest at $92.2 \%$ in snakes, followed by lizards $(83.7 \%)$ and turtles $(60.0 \%)$. The pathogen was also found in $81.2 \%$ of swabs taken from table and floor surfaces after reptile exhibitions and in two out of three egg samples. A total of 918 Salmonella strains belonging to 207 serovars and serological variants were obtained. We have noted the serovars considered important with respect to public health, i.e., S. Enteritidis, S. Typhimurium, and $S$. Kentucky. The study proves that exotic reptiles in Poland are a relevant reservoir of Salmonella.
\end{abstract}

Keywords: Salmonella; pet reptile; public health; reptile exhibition; antimicrobial resistance; improved methodology

\section{Introduction}

Reptiles are a well-known reservoir of a wide variety of Salmonella species, representing numerous subspecies and serovars. These poikilothermic vertebrates can be easily colonized with vertical and horizontal transfer and shed pathogens intermittently [1]. There are many reports of reptile-associated salmonellosis (RAS) in humans, mostly affecting children [2-4]. Contact with turtles and tortoises is considered to have a particularly high risk of infection [5,6]. Simultaneously, reptiles are popular pet animals in many countries. In recent decades, this has led to increased importation of reptiles and the creation of reptile breeding farms throughout Poland. Although there are no data from the European Union on the imports, more than 22,700 live reptiles were imported between 2008 and 2015 from non-EU countries, mainly from Africa and Asia (https:/ / www.mos.gov.pl/srodowisko/przyroda/ konwencje-miedzynarodowe/kowencja-waszyngtonska-cites/raporty-cites/, accessed on 16 March 2016). The easy availability, low price, and seemingly uncomplicated care and breeding of reptiles have made them popular pets, especially among young customers. Many reptile exhibitions take place in public spaces such as schools, universities, and exhibitions centers, providing the possibility not only to observe and admire the variety 
of reptile species but also often to touch and hold some of the individuals. Notably, the equipment used for these exhibitions (i.e., tables) is usually used for other daily activities.

The issue of microbiological hazards associated with reptiles kept in houses or zoos is rarely investigated in Poland, but a few reports are available [7-10]. The aim of this study was to further investigate the occurrence of Salmonella in exotic reptiles, including the serovar distribution and antimicrobial resistance of the strains, in the context of an improved detection procedure and public health concerns.

\section{Materials and Methods}

\subsection{Samples}

Over a three-year time period (2011-2013), 731 samples collected from reptiles and their environments were tested. A total of 696 fecal samples were taken from 662 healthy reptiles belonging to 45 species of snakes $(n=358 ; 51.4 \%), 58$ species of lizards $(n=276$; $39.6 \%), 24$ species of chelonians ( $n=60 ; 8.6 \%)$, and two crocodiles (Crocodylus niloticus). The samples were derived from 10 breeding farms $(n=258 ; 37 \%), 14$ pet shops $(n=143$; $20.5 \%), 5$ zoological gardens $(n=101 ; 14.5 \%), 1$ reptile shelter $(n=98 ; 14.1 \%)$, 3 reptile exhibitions $(n=41 ; 5.9 \%)$, and 9 private owners $(n=55 ; 7.9 \%)$ (Table 1$)$.

Table 1. Number of tested samples regarding the sampling place and reptile taxa.

\begin{tabular}{|c|c|c|c|c|c|c|c|}
\hline \multirow{2}{*}{ Sampling Place } & \multicolumn{4}{|c|}{ Reptile Group } & \multirow{2}{*}{ Environment } & \multirow{2}{*}{ Eggs } & \multirow{2}{*}{ Total } \\
\hline & Chelonian & Crocodile & Lizard & Snake & & & \\
\hline Breeding farm & 1 & & 79 & 178 & & 3 & 258 \\
\hline Pet shop & 19 & & 76 & 48 & & & 143 \\
\hline Private household & 5 & & 15 & 35 & & & 55 \\
\hline Reptile exhibition & 22 & & 8 & 11 & 32 & & 41 \\
\hline Reptile shelter & 5 & & 43 & 50 & & & 98 \\
\hline Zoological garden & 19 & 2 & 41 & 39 & & & 101 \\
\hline \multirow{2}{*}{ Total } & 60 & 2 & 276 & 358 & & & \\
\hline & \multicolumn{4}{|c|}{696} & 32 & 3 & 731 \\
\hline
\end{tabular}

Forty-one of the 696 fecal samples were obtained during a long-term study concerning intermittent Salmonella shedding conducted on 10 different reptiles from a reptile shelter and a private owner. Samples were collected up to five times from a single animal in at least two-month intervals.

Thirty-two environmental swabs were taken from four different reptile exhibitions from tables ( 3 rows, $n=24$ ) and floors (boot swabs, $n=8$ ). Half of these samples were collected before the start of the reptile exhibitions (after disinfection of the surfaces) and the other half were collected after the exhibitions.

Three pooled samples of unfertilized gecko eggs from 1 breeding farm were investigated. The egg shells and contents were tested separately.

All samples were stored for up to $72 \mathrm{~h}$ at $2-8^{\circ} \mathrm{C}$ before testing.

\subsection{Isolation and Identification of Salmonella}

Salmonella isolation was performed according to the PN-EN ISO 6579:2003/A1:2007 standard. Half of the fecal samples $(351 / 696 ; 50.4 \%)$ were tested using an improved methodology. Besides standard pre-enrichment (Buffered Peptone Water, BWP, Merck, Darmstadt, Germany) followed by selective enrichment (Modified Semisolid RappaportVassiliadis, MSRV, Merck, Germany), it included a simultaneous streak of $10 \mu \mathrm{L}$ BWP culture on a RAPID'Salmonella agar medium (RSA, BIO-RAD, California, CA, USA). After incubation $\left(37 \pm 1{ }^{\circ} \mathrm{C} ; 24 \pm 3 \mathrm{~h}\right.$ ), up to three suspected magenta colonies were subcultured on a Xylose Lysine Deoxycholate agar medium (XLD, Oxoid, Hampshire, UK). In the standard approach, the XLD medium was complemented with BxLH (in-house, PIWet, Puławy Poland) [11]. This led to a selection of several colonies with typical Salmonella 
morphology being subcultured on nutrient agar (BioMaxima, Lublin Poland) based on tiny differences in their size, shape, or color intensity. Biochemical confirmation was performed with conventional tests described elsewhere [12-14]. In-house media were applied, as well as multiplex PCR [15], which was used to reveal or confirm unclear biochemical confirmation of Salmonella species and subspecies. Serotyping was carried out according to the White-Kauffmann-Le Minor scheme [13]. To avoid duplicates, if isolates representing the same serogroup were detected on both MSRV and RSA, those from MSRV were selected for further investigation. Salmonella strains were stored $\left(2-8{ }^{\circ} \mathrm{C}\right)$ for further testing and deep-frozen until use.

\subsection{Antimicrobial Susceptibility Testing}

A subset of strains $(n=533)$ was selected for testing antimicrobial resistance based on the serovar and isolation source and location. In the case of the presence of different serovars in the same sample, strains representing each of the serovars were tested. Susceptibility testing was performed using the microbroth dilution method [16] (Sensititre EUVMS plates; TREK Diagnostic Systems, ThermoFisher Scientific, Waltham, MA, USA) for 14 compounds representing eight antimicrobial classes: beta-lactams (ampicillin, cefotaxime, and ceftazidime), quinolones (nalidixic acid), fluoroquinolones (ciprofloxacin), phenicols (chloramphenicol and florfenicol), aminoglycosides (gentamycin, kanamycin, and streptomycin), folate pathway inhibitors (trimethoprim and sulfamethoxazole), tetracyclines (tetracycline), and polymyxins (colistin). Strains were considered microbiologically resistant (non-wild-type, NWT) when the minimum inhibitory concentration (MIC) for each antimicrobial substance was above the epidemiological cut-off value (EUCAST, http:/ / www.eucast.org/mic_distributions_and_qc/, accessed on 27 January 2021) The WhoNet (v.5.6) software was used for MIC data management (https:/ /www.who.int/ medicines/areas / rational_use/AMR_WHONET_SOFTWARE/en/, accessed on 27 January 2021).

\subsection{Statistical Analysis}

The KyPlot software (v.5.0) was used to perform $\chi^{2}$ independence test calculations.

\section{Results}

\subsection{Salmonella Occurrence and Serovar Distribution}

Overall, Salmonella was detected in $85.8 \%(597 / 696 ; 95 \%$ CI $=83.2 \div 88.4 \%)$ of fecal samples, found in $92.2 \%(89.4 \div 95.0 \%)$ of snakes, $83.7 \%(79.3 \div 88.1 \%)$ of lizards, and $60 \%$ $(47.6 \div 72.4 \%)$ of chelonians. Both crocodile samples were negative. Differences between the taxa were statistically significant $(p \leq 0.001)$.

The occurrence of Salmonella, depending on the place of sampling, ranged from $74.3 \%$ in zoos to $91.8 \%$ in the reptile shelter $(p>0.05)$ (Figure 1). All surface swabs taken before the reptile exhibitions were negative for Salmonella, but the pathogen was confirmed in $81.2 \%(13 / 16)$ of swabs taken after the exhibitions. Two out of the three egg samples also contained Salmonella. Longitudinal testing of selected animals revealed that nine had shed Salmonella constantly, and one was negative throughout the whole study period. The number of positive samples and the obtained serovars differed between individuals and ranged from one in the mourning gecko to five in the savannah monitor and ground rattlesnake (Table 2). In two reptiles (mourning gecko and African puff adder), one serovar was isolated throughout the study period. 


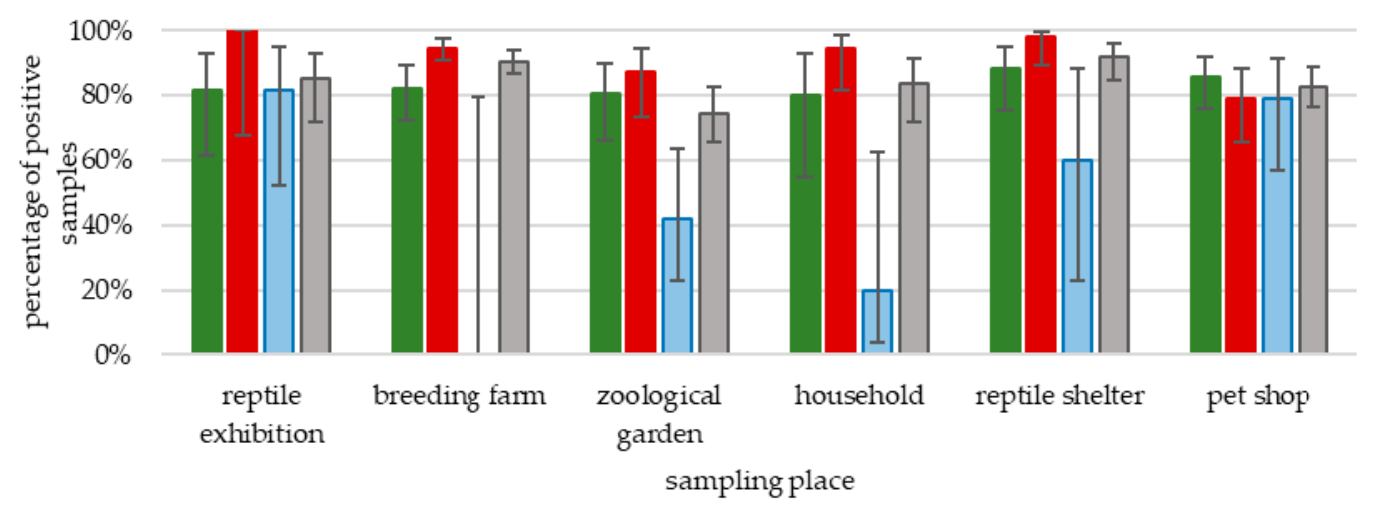

$\square$ lizards $\square$ snakes $\square$ chelonians $\square$ all

Figure 1. Prevalence of Salmonella by animal taxa and sampling place.

Table 2. Salmonella serovars found in fecal samples of reptiles tested periodically.

\begin{tabular}{|c|c|c|c|c|c|c|c|}
\hline \multirow{2}{*}{ Sampling Place } & \multirow{2}{*}{ Reptile Species } & \multirow{2}{*}{ Salmonella Serovar } & \multicolumn{5}{|c|}{ Sampling No. } \\
\hline & & & 1 & 2 & 3 & 4 & 5 \\
\hline \multirow{4}{*}{$\begin{array}{l}\text { Reptile } \\
\text { shelter }\end{array}$} & \multirow{4}{*}{$\begin{array}{l}\text { Mexican kingsnake } \\
\text { (Lampropeltis mexicana) }\end{array}$} & Fluntern & $\mathrm{x}$ & $x$ & & & \\
\hline & & Tennessee & & $x$ & & $x$ & \\
\hline & & II $30: 1, z_{28}: z_{6}$ & & & $x$ & & \\
\hline & & IIIb $14: z_{10}: z$ & & & $x$ & & $x$ \\
\hline \multirow{4}{*}{$\begin{array}{l}\text { Reptile } \\
\text { shelter }\end{array}$} & \multirow{4}{*}{$\begin{array}{l}\text { Saharan horned viper } \\
\quad \text { (Cerastes cerastes) }\end{array}$} & IIIlb 57:k:e,n,x,z 15 & $\mathrm{x}$ & & & & \\
\hline & & IIIb 53: $\mathrm{z}_{10}: \mathrm{z}_{35}$ & & $x$ & $x$ & $x$ & $x$ \\
\hline & & Fluntern & & & & $x$ & \\
\hline & & II $30: 1, z_{28}: z_{6}$ & & & & $x$ & \\
\hline \multirow{5}{*}{$\begin{array}{l}\text { Reptile } \\
\text { shelter }\end{array}$} & \multirow{5}{*}{$\begin{array}{l}\text { Ground rattlesnake } \\
\text { (Sistrurus miliarius) }\end{array}$} & Agona & $x$ & & & & \\
\hline & & II $30: 1, z_{28}: z_{6}$ & & $x$ & $x$ & $x$ & $x$ \\
\hline & & Mundonobo & & $x$ & & & $x$ \\
\hline & & IIIb 59:k:z & & $\mathrm{x}$ & & & \\
\hline & & IIIb 59:Z & & & & & $\mathrm{x}$ \\
\hline \multirow{3}{*}{$\begin{array}{l}\text { Reptile } \\
\text { shelter }\end{array}$} & \multirow{3}{*}{$\begin{array}{c}\text { Horned viper } \\
\text { (Vipera ammodytes) }\end{array}$} & IIIlb 57:1,v:Z 35 & $\mathrm{x}$ & & & & \\
\hline & & II $30: 1, z_{28}: z_{6}$ & & $x$ & $x$ & & \\
\hline & & IIIb 59:k:z & & & $x$ & & \\
\hline \multirow{2}{*}{$\begin{array}{l}\text { Reptile } \\
\text { shelter }\end{array}$} & \multirow{2}{*}{$\begin{array}{l}\text { Green iguana } \\
\text { (Iguana iguana) }\end{array}$} & II $30: 1, z_{28}: z_{6}$ & $x$ & $x$ & & $x$ & $x$ \\
\hline & & Tennessee & & & $\mathrm{x}$ & $x$ & $x$ \\
\hline \multirow{5}{*}{$\begin{array}{l}\text { Reptile } \\
\text { shelter }\end{array}$} & \multirow{5}{*}{$\begin{array}{c}\text { Savannah monitor } \\
\text { (Varanus exanthematicus) }\end{array}$} & Jangwani & $x$ & & & & \\
\hline & & Cubana & & $x$ & $x$ & & \\
\hline & & Overschie & & $x$ & & $x$ & \\
\hline & & IIIb 50:z:Z52 & & $x$ & & & \\
\hline & & Tennessee & & & & $\mathrm{x}$ & \\
\hline $\begin{array}{l}\text { Reptile } \\
\text { shelter }\end{array}$ & $\begin{array}{c}\text { Mourning gecko } \\
\text { (Lepidodactylus lugubris) }\end{array}$ & Infantis & $x$ & $\mathrm{x}$ & $x$ & $x$ & $x$ \\
\hline \multirow{4}{*}{$\begin{array}{l}\text { Reptile } \\
\text { shelter }\end{array}$} & \multirow{4}{*}{$\begin{array}{l}\text { Indian python } \\
\text { (Python molurus) }\end{array}$} & IV 42:Z36:- & $x$ & & & & \\
\hline & & Fluntern & & $x$ & $x$ & $x$ & \\
\hline & & Infantis & & & $x$ & & \\
\hline & & Redlands & & & & $\mathrm{x}$ & \\
\hline $\begin{array}{c}\text { Private } \\
\text { household }\end{array}$ & $\begin{array}{l}\text { Russian tortoise } \\
\text { (Testudo horsfieldii) }\end{array}$ & - & - & - & - & & \\
\hline \multirow{3}{*}{$\begin{array}{l}\text { Reptile } \\
\text { shelter }\end{array}$} & \multirow{3}{*}{$\begin{array}{l}\text { African puff adder } \\
\quad \text { (Bitis arietans) }\end{array}$} & Muenchen & $x$ & $x$ & $x$ & $x$ & $x$ \\
\hline & & IIIb 57:k:e,n,x, $z_{15}$ & & $x$ & $x$ & & \\
\hline & & IIIb 50:r:z & & & $x$ & & \\
\hline
\end{tabular}


Environmental samples yielded 27 strains belonging to 21 different serovars (Table 3). The number of strains was different depending on the reptile exhibition, ranging from 2 to 10.

Table 3. Salmonella serovars isolated from swabs taken after the reptile exhibitions.

\begin{tabular}{|c|c|c|c|c|}
\hline Sampling Site & Exhibition No. 1 & Exhibition No. 2 & Exhibition No. 3 & Exhibition No. 4 \\
\hline Tables-row no. 1 & IIIa 41:z $\mathrm{z}_{4}, \mathrm{z}_{23}:-$ & $\begin{array}{c}\text { IIIb 53: } \mathrm{Z}_{10}: \mathrm{Z}_{35} \\
\text { Tennessee } \\
\text { Adelaide }\end{array}$ & - & - \\
\hline Tables-row no. 2 & II $30: 1, z_{28}: z_{6}$ & $\begin{array}{l}\text { Enteritidis } \\
\text { Typhimurium } \\
\text { IV } 48: \mathrm{z}_{4}, \mathrm{z}_{32}:-\end{array}$ & Kentucky & 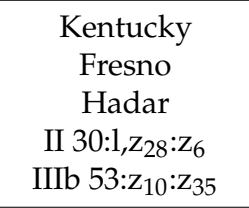 \\
\hline Tables_row no. 3 & $\begin{array}{c}\text { Tsevie, } \\
\text { Apeyeme }\end{array}$ & $\begin{array}{l}\text { Oranienburg } \\
\text { II } 1,40: \mathrm{g}, \mathrm{m}, \mathrm{t}\end{array}$ & - & Kentucky \\
\hline Floor & $\begin{array}{l}\text { Fluntern, } \\
\text { Ituri, } \\
\text { IIIb 48:Z52:z }\end{array}$ & $\begin{array}{l}\text { Enteritidis } \\
\text { V 48: } \mathrm{z}_{4}, \mathrm{z}_{32}:-\end{array}$ & II 41:g,t:- & $\begin{array}{c}\text { Miami } \\
\text { Muenchen }\end{array}$ \\
\hline
\end{tabular}

A total of nine strains belonging to six different serovars within two subspecies of $S$. enterica were obtained from the egg samples (Table 4). Different serovars were found in the egg contents and shells. S. II 50:b: $\mathrm{z}_{6}$ was isolated exclusively from the egg content, whereas $S$. Tennessee was also found in the eggshells. All of the strains found in these samples were also isolated from the feces of reptiles from the same reptile farm.

In $30.8 \%(n=184)$ of fecal samples obtained from lizards $(n=80)$, snakes $(n=96)$, and chelonians $(n=8)$, two different Salmonella serovars per sample were found. Three serovars per sample were detected in $7.5 \%(n=44)$ of samples, and four different serovars were identified in three samples from snakes and a lizard.

From 612 positive samples, 918 Salmonella strains belonging to 207 serovars and serological forms were identified. Among the 534 strains obtained from samples tested with the modified isolation method, $113(21 \%)$ were detected on RSA plates and not isolated on MSRV medium from the same sample (Supplementary Table S1). Most of those strains belonged to $S$. II 58:a: $\mathrm{z}_{6}(n=8), S$. Newport $(n=8), S$. II 1, $\mathrm{z}_{13}, \mathrm{z}_{28}: \mathrm{z}_{6}(n=7)$, and $S$. Fluntern $(n=5)$. Forty-six serovars were represented with single strains. Strains belonging to $S$. II

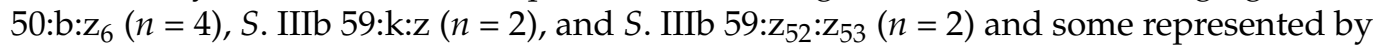
single strains were not isolated on MSRV during the research (Supplementary Table S1).

More than $66.4 \%(n=610)$ of strains were classified as S. enterica subsp. enterica (I), followed by subsp. salamae (II) $(14.6 \% ; n=134)$, subsp. diarizonae (IIIb) $(11.2 \% ; n=103)$, subsp. arizonae (IIIa) $(4.0 \% ; n=36)$, and S. enterica subsp. houtenae (IV) $(3.7 \% ; n=34)$. A single isolate was classified as $S$. bongori $48: \mathrm{z}_{65}:-(\mathrm{V})$. The serovars are listed in Table 4 . In total, $97 \%$ of isolates belonging to $S$. enterica subsp. arizonae and $84.0 \%$ to $S$. enterica subsp. diarizonae were isolated from snakes $(p \leq 0.001)$. S. enterica subsp. salamae dominated in lizards over snakes $(73.2 \% ; p \leq 0.001)$. The most prevalent serovar was $S$. Oranienburg $(n=54)$, followed by $S$. enterica subsp. salamae $30: 1, \mathrm{z}_{28}: \mathrm{z}_{6}(n=53), S$. Tennessee $(n=46)$, $S$. Agona $(n=43), S$. Muenchen $(n=43)$, S. Fluntern $(n=42)$, and $S$. II $1,40: \mathrm{g}, \mathrm{m}, \mathrm{t}:-(n=29)$ (Figure 2). S. Agona, S. Enteritidis, S. Muenchen, $S$. Oranienburg, $S$. Newport, and $S$. IIIb 53: $\mathrm{Z}_{10}: \mathrm{Z}_{35}$ were the most frequent in snakes (respectively: $p \leq 0.001, p \leq 0.05, p \leq 0.05$, $p \leq 0.01, p \leq 0.05$, and $p \leq 0.01$ ), whereas $S$. Tennessee, $S$. II 30:1, $\mathrm{z}_{28}: \mathrm{z}_{6}, S$. Ago, $S$. Monschaui, and $S$. Fluntern dominated in lizards (respectively: $p \leq 0.001, p \leq 0.001, p \leq 0.01, p \leq 0.01$, and $p \leq 0.01)$. No serovars were predominant in chelonians.

A single S. enterica subsp. enterica 47: $\mathrm{z}_{4}, \mathrm{z}_{23}$ :- strain was confirmed at Institut Pasteur, Paris, France, as a new Salmonella serovar. Six others were auto-agglutinating. Furthermore, 136 serovars $(65.7 \%)$ were reported for the first time in Poland. 
Table 4. Salmonella serovars found in fecal samples and eggs.

\begin{tabular}{|c|c|c|c|}
\hline & Source of Isolation & Fecal Samples & Unhatched Eggs \\
\hline \multirow[t]{5}{*}{$\begin{array}{l}\text { Salmonella } \\
\text { enterica } \\
\text { subsp. }\end{array}$} & enterica (610) & $\begin{array}{l}\text { Abony (1), Adelaide (10), Ago (10), Agona (43), Alachua (3), } \\
\text { Anatum (1), Apapa (4), Aqua (6), Baildon (1), Bardo (1), Bareilly (1), } \\
\text { Benin (4), Bispebjerg (1), Blijdorp (2), Blukwa (1), Bolombo (2), } \\
\text { Braenderup (3), Brandenburg (1), Carrau (5), Chicago (1), } \\
\text { Choleraesuis var. Decatur (1), Cotham (3), Cubana (8), Derby (2), } \\
\text { Durban (1), Eastbourne (2), Ekpoui (3), Enteritidis (10), Florida (9), } \\
\text { Fluntern (39), Fomeco (1), Fresno (3), Gaminara (1), Gatuni (5), } \\
\text { Glostrup (3), Hadar (10), Hofit (1), Ilala (1), Infantis (18), Inverness } \\
\text { (2), Itami (1), Jangwani (3), Jodhpur (2), Johannesburg (2), Kentucky } \\
\text { (20), Kintambo (14), Kisarawe (1), Koketime (1), Labadi (1), } \\
\text { Larochelle (1), Lattenkamp (6), Lisboa (1), Lome (1), Madelia (1), } \\
\text { Manhattan (2), Miami (6), Minnesota (2), Monschaui (10), } \\
\text { Montevideo (7), Mountpleasant (1), Muenchen (41), Muenster (2), } \\
\text { Mundonobo (5), Naware (1), Newport (19), Nima (6), Oranienburg } \\
\text { (53), Oritamerin (1), Orlando (1), Oslo (2), Othmarschen (1), } \\
\text { Overschie (2), Panama (2), Paratyphi B v. Java (13), Patience (1), } \\
\text { Poano (9), Pomona (19), Poona (3), Reading (1), Redlands (1), } \\
\text { Rosslyn (2), Saintpaul (1), Sandiego (1), Senftenberg (2), Singapore } \\
\text { (2), Tanzania (1), Teddington (3), Telelkebir (3), Tennessee (43), } \\
\text { Tonev (1), Toucra (1), Treforest (1), Typhimurium (6), Urbana (3), } \\
\text { Uzaramo (2), Virginia (1), 35:-:- (1), 4,5:b:- (6), 4:eh:- (6), 45:b:- (5), } \\
\text { 47:z4,z23:- (1), 6,8:-:- (1), Salmonella sp. (rough) (3) }\end{array}$ & $\begin{array}{l}\text { Tennessee (2), } \\
\text { Fluntern (2), Fresno } \\
\text { (1), Kentucky (1) }\end{array}$ \\
\hline & salamae (134) & 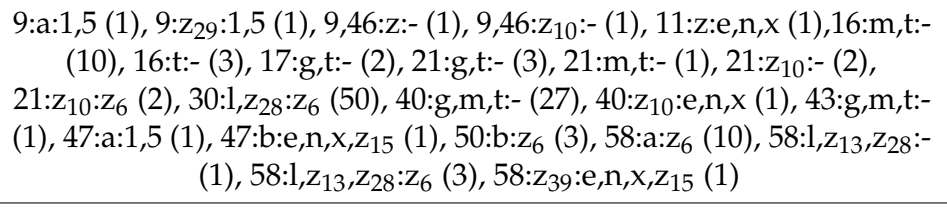 & $\begin{array}{c}40: \mathrm{g}, \mathrm{m}, \mathrm{t}:-(2) \\
50: \mathrm{b}: \mathrm{z}_{6}(1)\end{array}$ \\
\hline & arizonae (36) & 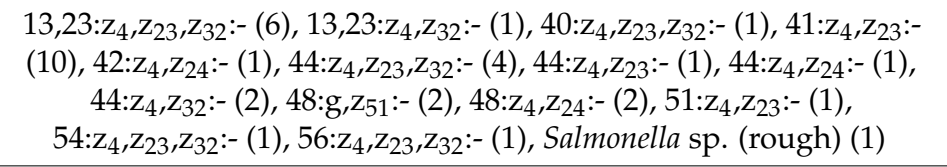 & \\
\hline & diarizonae (103) & 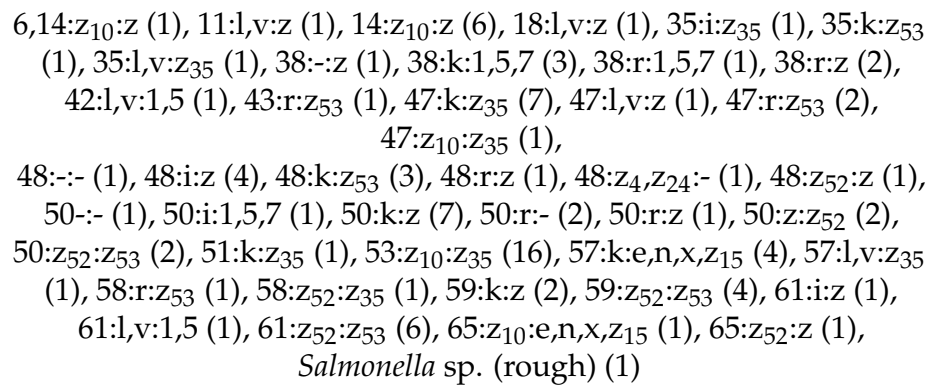 & \\
\hline & houtenae (34) & $\begin{array}{c}11: z_{4}, z_{23}:-(2), 16: z_{4}, z_{32}:-(2), 38: z_{4}, z_{23}:-(4), 40: z_{4}, z_{24},-(1), 41: z_{4}, z_{23}:- \\
(1), 42: z_{36}:-(3), 43: z_{4}, z_{23}:-(2), 44: z_{4}, z_{23}:-(6), 44: z_{4}, z_{24}:-(1), 45: g, z_{51}:- \\
\text { (3), 48:g,z51:- (2), 50:g, } z_{51}:-(1), 51: z_{4}, z_{23}:-(1), 53: g, z_{51}:-(2) \\
\text { Salmonella sp. (rough) (1) }\end{array}$ & \\
\hline
\end{tabular}




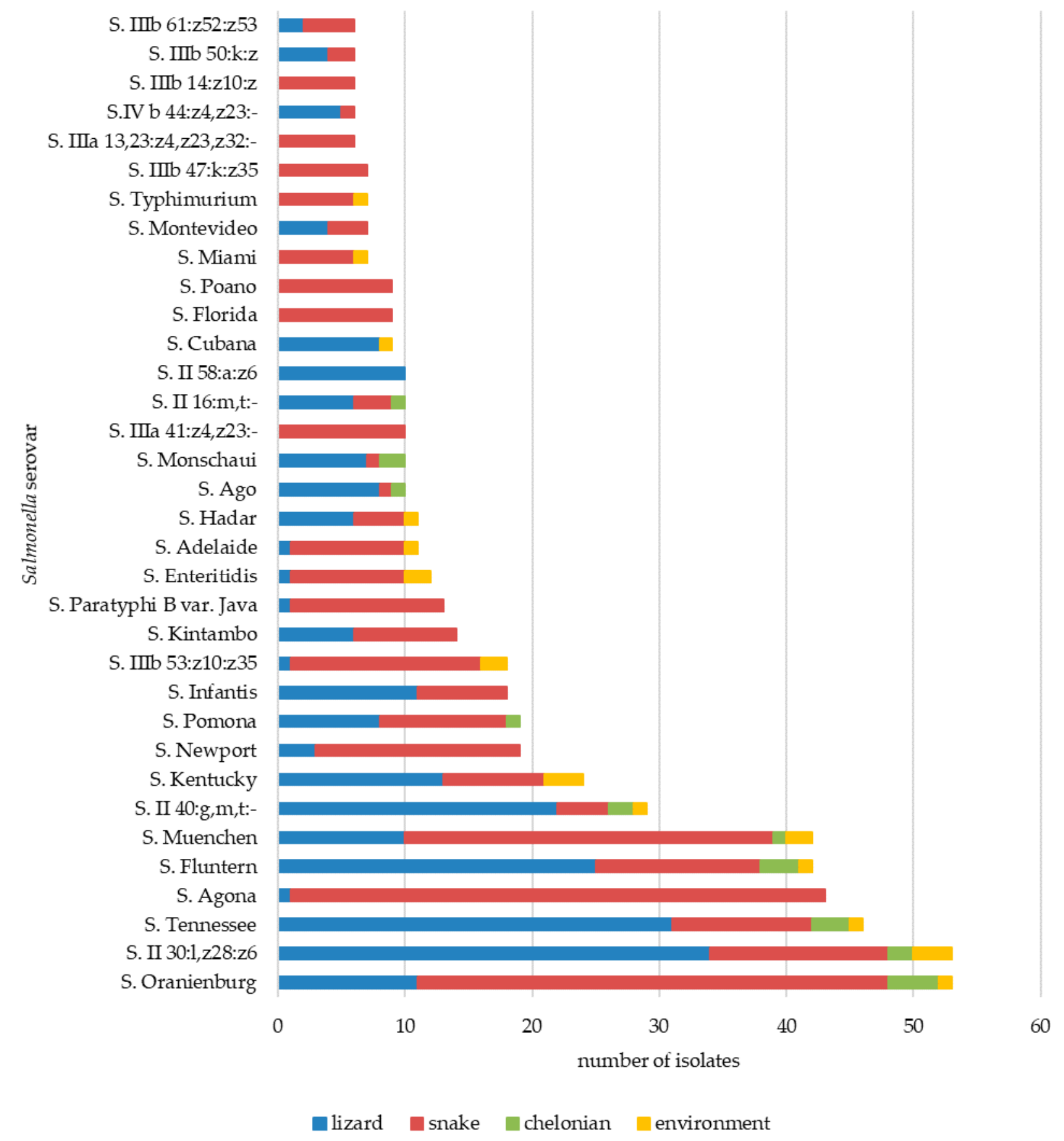

Figure 2. Distribution of the most prevalent Salmonella serovars found in animal taxa and their environments.

\subsection{Antimicrobial Resistance}

Amongst 533 tested strains, more than $67.2 \%$ were susceptible to all tested antimicrobials. Most commonly, the strains were resistant to streptomycin (25.0\%), ciprofloxacin $(8.1 \%)$, and nalidixic acid $(8.1 \%)$.

Single strains were resistant to tetracycline $(n=14 ; 2.6 \%)$, sulfamethoxazole $(n=13$; $2.4 \%)$, ampicillin $(n=8 ; 1.5 \%)$, kanamycin $(n=5 ; 0.9 \%)$, trimethoprim $(n=3 ; 0.6 \%)$, colistin $(n=2 ; 0.4 \%)$, chloramphenicol $(n=1 ; 0.2 \%)$, and gentamycin $(n=1 ; 0.2 \%)$. Resistant isolates belonged mostly to the subspecies S. enterica subsp. enterica, followed by S. enterica subsp. diarizonae. S. bongori isolate was susceptible to all tested antimicrobials. Resistance to quinolones in S. enterica subsp. enterica $(12.1 \%, p \leq 0.001)$ appeared significantly higher compared to that in other Salmonella subspecies. It was also identified as being the most prevalent in breeding farms $(16.4 \%, p \leq 0.05)$ and in samples taken from snakes $(13.2 \%$, 
$p \leq 0.001)$. Of the public health-relevant serovars deriving from different reptiles, isolates of $S$. Kentucky $(n=3)$ were classified as multi-drug resistant (MDR). Over $90 \%$ of $S$. Agona and $60 \%$ of $S$. Adelaide isolates were resistant to ciprofloxacin and nalidixic acid, whereas $S$. Typhimurium was susceptible to all tested antimicrobials.

\section{Discussion}

The popularity of captive reptiles as pets is continuously increasing. Therefore, recognition of the hazards associated with pet reptiles is becoming critical to avoid their negative consequences for human health. Our study, covering a broad collection of samples, confirmed that pet reptiles and their environments constitute a considerable reservoir of Salmonella. Moreover, a number of Salmonella strains noted in this study belonged to serovars of public health concern, i.e., Enteritidis, Typhimurium, Infantis, Hadar, Newport, Oranienburg, and Muenchen. The occurrence of those serovars has also been reported by previous studies on reptiles [4,17-19]. It is believed that in some cases, Salmonella may have been delivered with poultry meat [7]. However, it should be pointed out that although these were identified as "public health risks", all serovars of Salmonella have the potential to infect humans and result in salmonellosis. There were no confirmed cases of RAS in Poland, but one study suggests an epidemiological relation between $S$. Lindern isolates found in infants and tortoises [20]. In particular, regarding RAS, testing of the reptile exhibition environment samples seems to be crucial. Essentially, the current study has shown that at least two positive samples were obtained after each reptile exhibition. Many Salmonella isolates, including $S$. Kentucky and $S$. Enteritidis, were detected both in samples taken from the tables and floor. The use of general purpose school or hall equipment during exhibitions can have adverse consequences for humans. Many authors pay particular attention to the risk posed by Salmonella in educational centers where children are in direct contact with reptiles and in places where both humans and animals dwell [21-24]. Some studies also indicate that in some cases, this pathogen can be less common in reptiles than in the habitat of the reptiles [25]. The high survival rate of Salmonella in the environment allows the pathogen to survive in the terrarium long after the infected animals have been removed [26,27]. It follows that direct contact with a reptile is not necessary for the transmission of Salmonella.

Similar to other studies, a high prevalence of Salmonella was found, particularly in snakes and lizards [28]. According to Kepel et al., representatives of these reptile groups, especially Boinae, Iguanidae, and Chamaelonidae, are the most popular among reptiles available in the country [29]. Isolates belonging to S. enterica subsp. arizonae and S. enterica subsp. diarizonae seemed to be snake-related, which has been proven by others [30,31]. The obtained results indicate that Salmonella may be present in the majority of reptile-keeping households. Some lizards, such as leopard geckos, are considered easy to breed and are often recommended to people interested in reptiles. Additionally, amongst many reptile farmers, the knowledge about Salmonella carriage in reptiles and its possible consequences often remains at a basic level. Our study has shown no differences in the occurrence of this pathogen depending on the place of reptile origin. It is also congruent with others indicating a considerably high occurrence of Salmonella among reptiles kept in captivity $[17,18,30,32]$. A high-density reptile population promotes the transfer of the pathogen between animals. Moreover, using undisinfected equipment and feeding with rodents and one-day-old chicks are additional factors leading to the spread of Salmonella [7,33-35].

There is little information about the mechanism of vertical transmission of Salmonella in reptiles [1,36]. In this study, all Salmonella serovars isolated from both the egg contents and the eggshells were also found in the leopard gecko individuals from which the eggs were derived. The presence of this bacterium in egg content might prove the role of vertical transmission in the spread of Salmonella in reptile populations, but this should be investigated in future studies. In the case of some reptiles that take care of eggs and young cubs, such as crocodiles or royal cobras, horizontal transmission should also be taken into account. It makes this research area even more interesting and worth exploring. 
The rate of Salmonella detection can differ significantly by the animal specimen, habitat, type of sample, and, finally, the methodology used $[18,25,37]$. The additional step in the standardized methodology applied in this study led to an approximately $21 \%$ increase in the Salmonella serovar detection rate and allowed to identify multiple Salmonella serovars in $38 \%$ of samples. A possible explanation is various selectivity of the RSA and MRSV media in relation to different serovars [38]. Different numbers of colony-forming units and competition between multiple Salmonella strains present in the same mixture may influence the detection of only selected serovars [38]. Confirmation of more than one suspected colony from selective media, especially with visible differences in morphology, can significantly improve the assessment of the real serovar prevalence in reptile samples. The results suggest that if a sample is contaminated by more than one Salmonella serovar, some of them might be missed in the standard approach. Therefore, dedicated protocols and special attention for Salmonella detection in reptiles should be recommended.

In contrast to the results obtained by Goupil et al., indicating periodic shedding of Salmonella in snake feces, our research showed that the majority of the animals tested excreted the pathogen constantly [33]. This may be associated with the mostly bad health condition of the reptiles and the high level of stress occurring in animals submitted to the reptile shelter. Simultaneously, in most cases, one serovar was dominant and was found several times during the research interval, which has also been observed in other studies [33]. The obtained results suggest that Salmonella serovar diversity can be very high in an individual, but only multiple testing of the animal presents the possibility to prove this.

Overall, the antimicrobial resistance of the Salmonella found in reptiles remained low compared to food-producing animals [39]. Single multidrug-resistant isolates were found in different reptile species, with $S$. Kentucky being found most often [7]. A possible reason for the increasing antimicrobial resistance in reptile isolates may be the overuse of such drugs during treatment, or feeding with rodents or meat contaminated with MDR Salmonella isolates [40]. Therefore, carnivore reptiles should be taken into account as a possible vector of infection with multidrug-resistant Salmonella.

\section{Conclusions}

The study demonstrates the important role of reptiles as a reservoir for Salmonella, representing a variety of serovars, susceptible or multidrug resistant, being a potential hazard to humans. The obtained results justify the need for the education of reptile owners and monitoring of the occurrence of Salmonella in their pets. Every potential owner should be advised on the risk of Salmonella infection. If an event of diarrheal or bacteremic disease occurs in the family or other persons in contact with the animal, the doctor should be informed about this potential source of infection. This also applies to reporting attendance at reptile exhibitions. On the other hand, attention should be paid to proper decontamination of the environment and equipment following such events. Introduction of dedicated disinfection procedures would limit the risk of not only RAS but also other zoonotic bacteria often found in reptiles. Considering the diversity of Salmonella as well as the impressive biodiversity, behavior, and habitat of reptiles, they will always be an intriguing object of fundamental studies.

Supplementary Materials: The following are available online at https:/ / www.mdpi.com/article/ 10.3390 /microorganisms9051012/s1. Table S1: Salmonella serovars $(n=151)$ isolated from different media from single samples: from MSRV, from both MSRV and RSA, and only from RSA. Serovars obtained exclusively from RSA $(n=25)$ are in bold.

Author Contributions: Conceptualization, M.Z.; methodology, M.Z. and D.W.; writing-original draft preparation, M.Z.; writing—review and editing, D.W., M.S., K.S., A.L., A.Ś.-W., R.K. and P.P. All authors have read and agreed to the published version of the manuscript.

Funding: This research received no external funding.

Institutional Review Board Statement: Not applicable. 
Informed Consent Statement: Not applicable.

Data Availability Statement: The data presented in this study are included in the manuscript and supplementary material.

Acknowledgments: The authors are grateful to Ilona Samcik and Danuta Wnuk (National Veterinary Research Institute, Puławy, Poland) for their skillful technical assistance.

Conflicts of Interest: The authors declare no conflict of interest.

\section{References}

1. Schroter, M.; Speicher, A.; Hofmann, J.; Roggentin, P. Analysis of the transmission of Salmonella spp. through generations of pet snakes. Environ. Microbiol. 2006, 8, 556-559. [CrossRef]

2. Bertrand, S.; Rimhanen-Finne, R.; Weill, F.X.; Rabsch, W.; Thornton, L.; Perevoščikovs, J.; van Pelt, W.; Heck, M. Salmonella infections associated with reptiles: The current situation in Europe. EuroSurveillance 2008, 13, 18902. [CrossRef] [PubMed]

3. Hydeskov, H.B.; Guardabassi, L.; Aalbaek, B.; Olsen, K.E.; Nielsen, S.S.; Bertelsen, M.F. Salmonella prevalence among reptiles in a zoo education setting. Zoonoses Public Health 2013, 60, 291-295. [CrossRef]

4. Pees, M.; Rabsch, W.; Plenz, B.; Fruth, A.; Prager, R.; Simon, S.; Schmidt, V.; Münch, S.; Braun, P.G. Evidence for the transmission of Salmonella from reptiles to children in Germany, July 2010 to October 2011. EuroSurveillance 2013, 18, 20634. [CrossRef] [PubMed]

5. Bosch, S.; Tauxe, R.V.; Behravesh, C.B. Turtle-associated salmonellosis, United States, 2006-2014. Emerg. Infect. Dis. 2016, 22, 1149-1155. [CrossRef] [PubMed]

6. Marin, C.; Vega, S.; Marco-Jimenez, F. Tiny turtles purchased at pet stores are a potential high risk for Salmonella human infection in the Valencian Region, Eastern Spain. Vector Borne Zoonotic Dis. 2016, 16, 455-460. [CrossRef] [PubMed]

7. Zając, M.; Wasyl, D.; Hoszowski, A.; Le Hello, S.; Szulowski, K. Genetic lineages of Salmonella enterica serovar Kentucky spreading in pet reptiles. Vet. Microbiol. 2013, 166, 686-689. [CrossRef] [PubMed]

8. Dudek, B.; Książczyk, M.; Krzyżewska, E.; Rogala, K.; Kuczkowski, M.; Woźniak-Biel, A.; Korzekwa, K.; Korzeniowska-Kowal, A.; Ratajszczak, R.; Wieliczko, A.; et al. Comparison of the phylogenetic analysis of PFGE profiles and the characteristic of virulence genes in clinical and reptile associated Salmonella strains. BMC Vet. Res. 2019, 15, 312. [CrossRef]

9. Goławska, O.; Zając, M.; Maluta, A.; Pristas, P.; Hamarová, E.; Wasyl, D. Complex bacterial flora of imported pet tortoises deceased during quarantine: Another zoonotic threat? Comp. Immunol. Microbiol. Infect. Dis. 2019, 65, 154-159. [CrossRef]

10. Zając, M.; Maluta, A.; Wasyl, D.; Skarżyńska, M.; Lalak, A.; Samcik, I.; Kwit, R.; Szulowski, K. Genetic relationship of Salmonella isolates found in subcutaneous abscesses in Leopard Geckos (Eublepharis macularius). J. Vet. Res. 2020, 64, 387-390. [CrossRef]

11. Hoszowski, A.; Truszczyński, M. Choice of the optimal method for the isolation of Salmonella from meat- and bone powder designed for industrial feed mixtures. Comp. Immunol. Microbiol. Infect. Dis. 1995, 18, 227-237. [CrossRef]

12. Edwards, P.R.; Ewing, W.H. Edwards and Ewing's Identification of Enterobacteriaceae; Elsvier Science Publishers Co. Inc.: New York, NY, USA; Amsterdam Fourth Edition: Oxford, UK, 1986.

13. Grimont, P.A.D.; Weill, F.-X. Antigenic Formulae of Salmonella Serovars, 9th ed.; WHO Collaborating Centre for Research on Salmonella, Institute Pasteur: Paris, France, 2017.

14. Hoszowski, A.; Truszczyński, M. Skrócona identyfikacja pałeczek Salmonella przy zastosowaniu metody czterech probówek. Med. Wet 1977, 33, 738-740.

15. Lee, K.; Iwata, T.; Shimizu, M.; Taniguchi, T.; Nakadai, A.; Hirota, Y.; Hayashidani, H. A novel multiplex PCR assay for Salmonella subspecies identification. J. Appl. Microbiol. 2009, 107, 805-811. [CrossRef]

16. International Organization for Standardization. ISO 20776-1:2006 Susceptibility Testing of Infectious Agents and Evaluation of Performance of Antimicrobial Susceptibility Test Devices_Part 1: Broth Micro-Dilution Reference Method for Testing the In Vitro Activity of Antimicrobial Agents against Rapidly Growing Aerobic Bacteria Involved in Infectious Diseases; International Organization for Standardization: Geneva, Switzerland, 2006; pp. 1-19.

17. Marin, C.; Ingresa-Capaccioni, S.; Gonzalez-Bodi, S.; Marco-Jimenez, F.; Vega, S. Free-living turtles are a reservoir for Salmonella but not for Campylobacter. PLoS ONE 2013, 8, e72350. [CrossRef] [PubMed]

18. Nakadai, A.; Kuroki, T.; Kato, Y.; Suzuki, R.; Yamai, S.; Yaginuma, C.; Shiotani, R.; Yamanouchi, A.; Hayashidani, H. Prevalence of Salmonella spp. in pet reptiles in Japan. J. Vet. Med. Sci. 2005, 67, 97-101. [CrossRef]

19. Pedersen, K.; Lassen-Nielsen, A.M.; Nordentoft, S.; Hammer, A.S. Serovars of Salmonella from Captive Reptiles. Zoonoses Public Health 2009, 56, 238-242. [CrossRef] [PubMed]

20. Dera-Tomaszewska, B. Epidemiology and pathogenicity of Salmonella Enteritidis and Salmonella serovars first isolated in Poland. Ann. Acad. Med. Gedanensis 2013, 43 (Suppl. 3), 1-238.

21. Bauwens, L.; Vercammen, F.; Bertrand, S.; Collard, J.M.; De Ceuster, S. Isolation of Salmonella from environmental samples collected in the reptile department of Antwerp Zoo using different selective methods. J. Appl. Microbiol. 2006, 101, $284-289$. [CrossRef]

22. Friedman, C.R.; Torigian, C.; Shillam, P.J.; Hoffman, R.E.; Heltzel, D.; Beebe, J.L.; Malcolm, G.; DeWitt, W.E.; Hutwagner, L.; Griffin, P.M. An outbreak of salmonellosis among children attending a reptile exhibit at a zoo. J. Pediatr. 1998, 132, 802-807. [CrossRef] 
23. Hamel, F.A.D.; McInnes, H.M. Lizards as vectors of human salmonellosis. J. Hyg. (Lond.) 1971, 69, 247-253. [CrossRef]

24. Jang, Y.H.; Lee, S.J.; Lim, J.G.; Lee, H.S.; Kim, T.J.; Park, J.H.; Chung, B.H.; Choe, N.H. The rate of Salmonella spp. infection in zoo animals at Seoul Grand Park, Korea. J. Vet. Sci. 2008, 9, 177-181. [CrossRef] [PubMed]

25. Wikstrom, V.O.; Fernstrom, L.L.; Melin, L.; Boqvist, S. Salmonella isolated from individual reptiles and environmental samples from terraria in private households in Sweden. Acta Vet. Scand. 2014, 56, 7. [CrossRef] [PubMed]

26. Centers for Disease Control and Prevention. Lizard-Associated Salmonellosis-Utah. Morb. Mortal. Wkly Rep. 1992, 41, 610-611.

27. Mermin, J.; Hutwagner, L.; Vugia, D.; Shallow, S.; Daily, P.; Bender, J.; Koehler, J.; Marcus, R.; Angulo, F.J. Reptiles, amphibians, and human Salmonella infection: A population-based, case-control study. Clin. Infect. Dis. 2004, 38 (Suppl. 3), S253-S261. [CrossRef] [PubMed]

28. Geue, L.; Loschner, U. Salmonella enterica in reptiles of German and Austrian origin. Vet. Microbiol. 2002, 84, 79-91. [CrossRef]

29. Kepel, A.; Kala, B.; Graclik, A. Ginace Gatunki w Sieci-Handel Okazami Zwierzat Zagrożonych Wyginięciem na Polskojęzycznych Stronach Internetowych; PTOP "Salamandra": Poznań, Poland, 2009; pp. 1-16, (In Polish). Available online: http:/ / www.salamandra.org.pl/DO_POBRANIA/CITES/RAPORT2009_NEW1.pdf (accessed on 4 May 2021).

30. Kuroki, T.; Ishihara, T.; Furukawa, I.; Okatani, A.T.; Kato, Y. Prevalence of Salmonella in wild snakes in Japan. Jpn. J. Infect. Dis. 2013, 66, 295-298. [CrossRef]

31. Schröter, M.; Roggentin, P.; Hofmann, J.; Speicher, A.; Laufs, R.; Mack, D. Pet snakes as a reservoir for Salmonella enterica subsp. diarizonae (Serogroup IIIb): A prospective study. Appl. Environ. Microbiol. 2004, 70, 613-615. [CrossRef]

32. Briones, V.; Tellez, S.; Goyache, J.; Ballesteros, C.; del Pilar Lanzarot, M.; Dominguez, L.; Fernandez-Garayzabal, J.F. Salmonella diversity associated with wild reptiles and amphibians in Spain. Environ. Microbiol. 2004, 6, 868-871. [CrossRef]

33. Goupil, B.A.; Trent, A.M.; Bender, J.; Olsen, K.E.; Morningstar, B.R.; Wunschmann, A. A longitudinal study of Salmonella from snakes used in a public outreach program. J. Zoo Wildl. Med. 2012, 43, 836-841. [CrossRef]

34. Harker, K.S.; Lane, C.; De Pinna, E.; Adak, G.K. An outbreak of Salmonella Typhimurium DT191a associated with reptile feeder mice. Epidemiol. Infect. 2011, 139, 1254-1261. [CrossRef]

35. Lee, K.M.; McReynolds, J.L.; Fuller, C.C.; Jones, B.; Herrman, T.J.; Byrd, J.A.; Runyon, M. Investigation and characterization of the frozen feeder rodent industry in Texas following a multi-state Salmonella Typhimurium outbreak associated with frozen vacuum-packed rodents. Zoonoses Public Health 2008, 55, 488-496. [CrossRef] [PubMed]

36. Chiodini, R.J. Transovarian passage, visceral distribution, and pathogenicity of Salmonella in snakes. Infect. Immun. 1982, 36, 710-713. [CrossRef] [PubMed]

37. Zając, M.; Wasyl, D.; Różycki, M.; Bilska-Zając, E.; Fafiński, Z.; Iwaniak, W.; Krajewska, M.; Hoszowski, A.; Konieczna, O.; Fafińska, P.; et al. Free-living snakes as a source and possible vector of Salmonella spp. and parasites. Eur. J. Wildl. Res. 2016, 62, 161-166. [CrossRef]

38. Gorski, L. Selective enrichment media bias the types of Salmonella enterica strains isolated from mixed strain cultures and complex enrichment broths. PLoS ONE 2012, 7, e34722. [CrossRef] [PubMed]

39. Wasyl, D.; Hoszowski, A.; Zając, M. Prevalence and characterisation of quinolone resistance mechanisms in Salmonella spp. Vet. Microbiol. 2014, 171, 307-314. [CrossRef]

40. Fuller, C.C.; Jawahir, S.L.; Leano, F.T.; Bidol, S.A.; Signs, K.; Davis, C.; Holmes, Y.; Morgan, J.; Teltow, G.; Jones, B.; et al. A multi-state Salmonella Typhimurium outbreak associated with frozen vacuum-packed rodents used to feed snakes. Zoonoses Public Health 2008, 55, 481-487. [CrossRef] 